\title{
PENILAIAN JENIS MULTIGEAR PADA USAHA PERIKANAN TANGKAP SKALA KECIL DI PERAIRAN SUNGSANG KABUPATEN BANYUASIN SUMATERA SELATAN
}

\author{
Assessment of Multigear Type at Small-Scale Fisheries in Sungsang Estuary Banyuasin \\ District South Sumatra
}

Oleh:

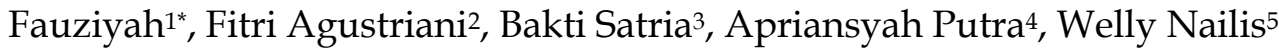

1Program Studi Ilmu Kelautan FMIPA Universitas Sriwijaya, Sumatera Selatan.sitiffauziyah@yahoo.com

2Program Studi Ilmu Kelautan FMIPA Universitas Sriwijaya, Sumatera Selatan.fitri_agustriani@yahoo.com

3Program Studi Ilmu Kelautan FMIPA Universitas Sriwijaya, Sumatera Selatan.bakti92@yahoo.com 4Jurusan Sistem Informasi Fakultas Ilmu Komputer Universitas Sriwijaya, Sumatera Selatan. apriansyah@unsri.ac.id

5Jurusan Manajemen Fakultas Ekonomi Universitas Sriwijaya, Sumatera Selatan.wellynailis@gmail.com

*korespondensi : fauziyah@unsri.ac.id

Diterima: 14 Maret 2017; Disetujui: 10 Oktober 2018

\begin{abstract}
Multigear has been commonly used in small-scale fishery activities in Sungsang waters. The aim of using the multigear is to enable the fishermen carry out their activities at every catching season. Inaccurate and inefficient use of the multigears are the concern that will present inefficiency or even conflict among the fishermen. Therefore the research was carried out with the objective to determine the best type of a multigear that will be used in the small scale fishery at Sungsang waters based on economic, productivity, social and biological aspects. Multiple Criteria Analysis (MCA) is the method of assessment on the quality type of the multigear. The outcome of the research presented that the best quality type of the multigear is 1) the multigear type with the combination of trammel net and drift longline; 2) the multigear type with the combination of drift gillnet (mesh, 3 inches) and drift long line; 3) the multigear type with the combination of drift gillnet (mesh, 2 inches) and trammel nets.
\end{abstract}

Key Words: MA analysis, small-scale fishery, the best quality multigear,

\section{ABSTRAK}

Multigear telah banyak digunakan pada usaha perikanan tangkap skala kecil di Perairan Sungsang. Tujuan penggunaan multigear adalah dikarenakan agar nelayan dapat terus melakukan aktivitas penangkapan dalam setiap musim penangkapan. Penggunaan multigear yang tidak tepat dan bijak, dikhawatirnya malah akan menimbulkan inefisiensi atau bahkan menimbulkan konflik antar nelayan. Oleh kerana itu, penelitian ini dilakukan dengan tujuan untuk menentukan jenis multigear unggulan pada usaha perikanan tangkap skala kecil di Perairan Sungsang berdasarkan aspek ekonomi, aspek produktivitas, aspek sosial, dan aspek biologi. Penilaian keunggulan jenis multigear menggunakan metoda Multiple Criteria Analysis (MCA). Hasil penelitian menunjukkan bahwa jenis multigear unggulan adalah: 1) jenis multigear dangan kombinasi jaring udang dan rawai hanyut; 2) jenis multigear dangan kombinasi jaring insang hanyut (mesh, 3 inci) 
dengan rawai hanyut (umpan), dan 3) jenis multigear dengan kombinasi jaring insang hanyut (mesh, 2 inci) dan jaring udang.

Kata kunci: MCA analysis, multigear unggulan, perikanan skala kecil

\section{PENDAHULUAN}

Kegiatan penangkapan ikan di Kabupaten Banyuasin Provinsi Sumatera Selatan dibedakan menjadi penangkapan ikan laut dan penangkapan ikan darat. Pada tahun 2014, perahu/kapal penangkapan ikan laut di Kabupaten Banyuasin terdiri dari perahu tanpa motor (466 unit), perahu motor tempel (705 unit), dan kapal motor (unit 2.308 unit). Kapal motor tersebut paling banyak terdapat di Kecamatan Banyuasin II (1.091 unit), selanjutnya di Kecamatan Muara Sugihan (512 unit) dan sisanya tersebar di 7 kecamatan (BPS 2015).

Perikanan tangkap skala kecil dapat diklasifikasikan berdasarkan karakteristik usaha yang dilakukan oleh nelayan. Dengan kata lain, nelayan yang melakukan usaha perikanan tangkap skala kecil diklasifikasikan sebagai nelayan kecil. Nelayan kecil menurut UU Nomor 45 Tahun 2009 tentang Perikanan adalah orang yang mata pencahariannya melakukan penangkapan ikan untuk memenuhi kebutuhan hidup sehari-hari dengan menggunakan kapal berukuran paling besar 5 GT.

Kegiatan usaha perikanan tangkap skala kecil di Kacamatan Banyuasin II dilakukan di perairan Sungsang. Berdasarkan data yang diperoleh dari sekretaris desa, ketua RT dan tokoh masyarakat setempat, 90,8\% usaha perikanan tangkap skala kecil di wilayah tersebut menggunakan kapal perikanan berukuran paling besar 5 GT. Sisanya, yaitu $9,2 \%$, menggunakan kapal berukuran lebih dari 5 GT.

Permasalahan teknis yang dihadapi oleh usaha perikanan tangkap skala kecil selain jangkauan penangkapan yang terbatas adalah rentan terhadap perubahan iklim dan perubahan ekosistem sumberdaya ikan target. Sehingga hasil tangkapannya kurang optimal. Nelayan Sungsang telah melakukan adaptasi/penyesuaian terhadap kondisi tersebut dengan mengoperasikan alat tangkap lebih dari satu dalam satu kapal (multigear) agar hasil tangkapannya lebih banyak. Berdasarkan hasil wawancara, jenis multigear yang digunakan merupakan kombinasi dari 7 jenis alat tangkap, yaitu: 1) jaring insang ha- nyut (drift gillnet); 2) jaring insang tetap (set gillnet); 3) jaring udang (trammel net); 4) pukat kantong (trawl); 5) serok (scoop net); 6) rawai (longline); dan 7) jermal. Adapun yang menjadi tujuan utama tangkapan nelayan Sungsang adalah jenis ikan kakap, cawang, kurisi, tongkol, tenggiri, senangin, kembung, gulamah, manyung, sembilang, parangparang, rajungan, udang, bawal, lidah, lais, bilis dan pari.

Berdasarkan hasil wawancara, penggunaan multigear telah dilakukan oleh nelayan setempat selama 5-10 tahun terakhir. Penggunaan multigear sampai saat ini tidak tercatat dalam data statistik perikanan. Fenomena penggunaan multigear juga telah dilakukan oleh nelayan kecil di daerah lain. Penelitian yang dilakukan oleh Wismaningrum et al. (2013) dan Yanuartono et al. (2011) menjelaskan penggunaan multigear oleh nelayan kecil di Kabupaten Kendal, Jawa Tengah. Nelayan menggunakan multigear pada musim yang berbeda sesuai dengan musim dan tingkah laku ekologis ikan target (Moutopoulus et al. 2014; Koeshendrajana et al. 2012; Wismaningrum et al. 2013; Yanuartono et al. 2011). Perubahan teknik penangkapan dari single gear ke multigear ini sebagai salah satu bentuk adaptasi. Hal ini mengingat bahwa perubahan tersebut merupakan proses yang dilakukan secara alamiah oleh nelayan untuk melakukan penyesuaian terhadap dinamika perubahan fishing ground dan perubahan ikan target. Penggunaan multigear memungkinkan jenis ikan target menjadi lebih banyak, sehingga hasil tangkapannya diharapkan dapat meningkat.

Jenis multigear yang digunakan oleh nelayan Sungsang bervariasi dan sampai saat ini belum pernah dikaji secara komprehensif. Beberapa penelitian di Perairan Sungsang hanya terkait jenis single gear seperti: bagan tancap (Fauziyah et al. 2012; Fauziyah et al. 2013), trammel net (Dwirastina dan Abidin 2013), strategi pengembangan perikanan pelagis (Rosalina 2011), dan peluang pengembangan perikanan tangkap (Septifitri et al. 2010).

Sebagai bagian dari unit penangkapan, penggunaan multigear tidak dapat di- 
pisahkan dari aspek ekonomi, aspek produktivitas, aspek biologi dan aspek sosial budaya. Aspek-aspek tersebut akan mempengaruhi kinerja multigear pada khususnya dan keberlanjutan usaha perikanan tangkap pada umumnya. Kajian penggunaan multigear secara komprehensif sangat penting untuk mengetahui kinerja dari setiap jenis multigear sehingga dapat ditentukan jenis multigear yang layak untuk dikembangkan. Pengembangan jenis multigear yang layak sangat penting untuk mendukung upaya pengelolaan usaha perikanan tangkap secara bertanggung jawab dan berkelanjutan di Kabupaten Banyuasin. Penelitian ini bertujuan untuk menentukan jenis multigear unggulan pada usaha perikanan tangkap skala kecil di Perairan Sungsang berdasarkan aspek ekonomi, produktivitas, sosial, dan biologi. Hasil penelitian ini diharapkan dapat digunakan sebagai pertimbangan bagi pengambil kebijakan dalam mengelola usaha perikanan tangkap skala kecil di Kabupaten Banyuasin.

\section{METODE}

Penelitian ini dilaksanakan pada bulan November 2014, bertempat di Kecamatan Banyuasin II Kabupaten Banyuasin Sumatera Selatan yakni di Desa Sungsang I, Desa Sungsang II, Desa Sungsang III, Desa Sungsang IV dan Desa Marga Sungsang. Lokasi penelitian dapat dilihat pada Gambar 1.

Metode pengumpulan data yang digunakan dalam penelitian ini adalah metode quota sampling. Quota sampling adalah teknik pengambilan sampling dalam bentuk distratifikasikan secara proposional, namun tidak dipilih acak. Adapun yang dijadikan sampel penelitian adalah subjek yang mudah ditemui dan memenuhi kriteria usaha kecil sehingga memudahkan proses wawancara dalam upaya pengumpulan data. Adapun jenis data yang dibutuhkan sebagai berikut:

1. Data hasil identifikasi jenis-jenis multigear yang digunakan pada usaha perikanan tangkap skala kecil dengan ukuran kapal 1-5 GT.

2. Data GT Kapal, daya mesin (PK) dan jumlah ABK pada setiap jenis multi-gear telah teridentifikasi sebagaimana poin 1.

3. Data hasil tangkapan $(\mathrm{kg})$ pada setiap unit penangkapan sebagaimana poin 2.

4. Data aspek produktivitas, ekonomi, sosial, dan biologi disajikan pada Tabel 1.

Tabel 1 menguraikan 5 jenis data aspek produksi (ukuran kapal, daya mesin, jenis multigear, produksi per trip, produksi per tahun), 8 jenis data aspek ekonomi (biaya investasi, biaya operasional, biaya perawatan, biaya penyusutan, nilai produksi, keuntungan, payback period dan revenue cost ratio), 4 jenis data aspek sosial (pendapatan nelayan per tahun, konflik antar nelayan, pertentangan dengan budaya setempat, dan pertentangan dengan peraturan setempat), dan 3 jenis data aspek biologi (jumlah species yang tertangkap, waktu musim penangkapan, dan persentase ikan target) terhadap hasil tangkapan).

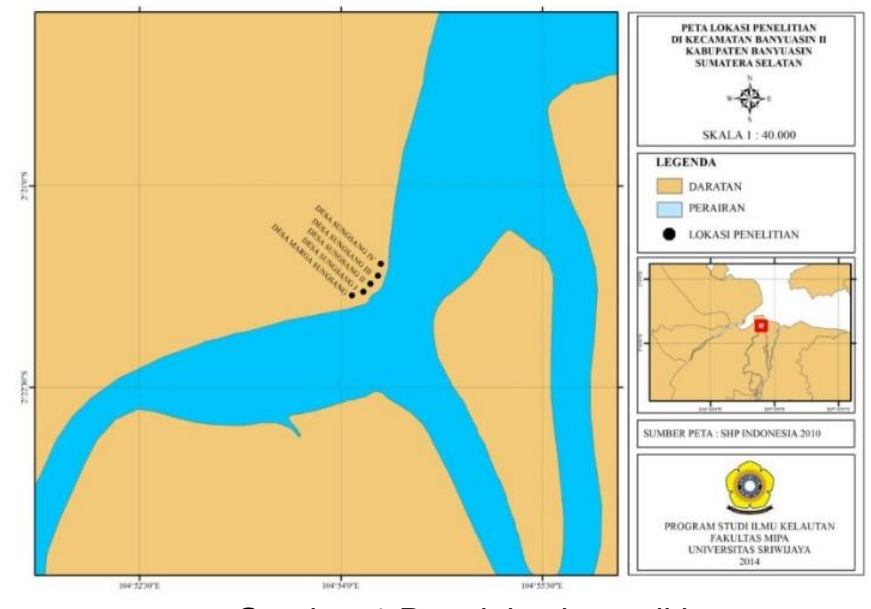

Gambar 1 Peta lokasi penelitian 
Tabel 1 Jenis data aspek produktivitas, aspek ekonomi, aspek sosial, dan aspek biologi

\begin{tabular}{|c|c|c|}
\hline & $\begin{array}{l}\text { Jenis data dan pengukuran } \\
\text { parameter }\end{array}$ & Uraian \\
\hline \multicolumn{3}{|c|}{ 1. Data aspek produktivitas: } \\
\hline & a. Ukuran kapal (GT) & $\begin{array}{l}\text { Perbedaan GT kapal berkaitan dengan jangkauan daerah } \\
\text { penangkapan dan kapasitas daya tampung hasil tangkapan }\end{array}$ \\
\hline & b. Daya mesin & $\begin{array}{l}\text { Perbedaan daya mesin yang digunakan berkaitan dengan } \\
\text { kecepatan kapal dalam mengoperasikan alat tangkap }\end{array}$ \\
\hline & c. Jenis multigear & $\begin{array}{l}\text { Perbedaan jenis multigear yang digunakan berkaitan } \\
\text { dengan teknik penangkapan, jenis ikan target, dan jumlah } \\
\text { hasil tangkapan }\end{array}$ \\
\hline & d. Produksi per trip & $\begin{array}{l}\text { Jumlah hasil tangkapan per trip yang dihasilkan oleh setiap } \\
\text { unit penangkapan yang menggunakan jenis multigear } \\
\text { tertentu. }\end{array}$ \\
\hline & e. Produksi per tahun & $\begin{array}{l}\text { Jumlah hasil tangkapan per tahun yang dihasilkan oleh } \\
\text { setiap unit penangkapan yang menggunakan jenis multigear } \\
\text { tertentu. }\end{array}$ \\
\hline \multicolumn{3}{|c|}{ 2. Data aspek ekonomi: } \\
\hline & a. Biaya investasi & $\begin{array}{l}\text { Biaya yang dikeluarkan untuk pengadaan kapal/perahu, } \\
\text { jenis multigear yang digunakan, mesin dan perlengkapan } \\
\text { lainnya. }\end{array}$ \\
\hline & b. Biaya operasional & $\begin{array}{l}\text { Biaya yang dikeluarkan saat melakukan kegiatan } \\
\text { penangkapan seperti, BBM, perbekalan, dan es. }\end{array}$ \\
\hline & c. Biaya perawatan & $\begin{array}{l}\text { Biaya yang dikeluarkan untuk pemeliharaan kapal, mesin, } \\
\text { jenis multigear, dan perlengkapan lainya }\end{array}$ \\
\hline & d. Biaya penyusutan & $\begin{array}{l}\text { Biaya yang dikeluarkan karena penyusutan nilai investasi } \\
\text { barang, seperti kapal, mesin dan jenis multigear. }\end{array}$ \\
\hline & e. Nilai produksi & $\begin{array}{l}\text { Berat produksi dikalikan harga persatuan berat pada tingkat } \\
\text { harga produsen yang dinyatakan dalam rupiah. }\end{array}$ \\
\hline & $\begin{array}{l}\text { Keuntungan, payback period, } \\
\text { revenue cost ratio, dan } \\
\text { pendapatan kotor }\end{array}$ & $\begin{array}{l}\text { Pengukuran ini berkaitan dengan tingkat kelayakan usaha } \\
\text { penangkapan skala kecil ketika menggunakan jenis } \\
\text { multigear tertentu. Nilai keuntungan, pendapatan dan } \mathrm{R} / \mathrm{C} \\
\text { ratio semakin besar baik tingkat kelayakan usahanya. } \\
\text { Sebaliknya, semakin kecil nilai payback period maka } \\
\text { semakin baik tingkat kelayakan usahnya. }\end{array}$ \\
\hline 3. & $\begin{array}{l}\text { Data aspek sosial: } \\
\text { a. Konflik antar nelayan }\end{array}$ & $\begin{array}{l}\text { Ada tidaknya konflik antar nelayan akibat penggunaan jenis } \\
\text { multigear }\end{array}$ \\
\hline & $\begin{array}{l}\text { b. Pertentangan dengan } \\
\text { budaya setempat }\end{array}$ & $\begin{array}{l}\text { Ada tidaknya penggunaan jenis multigear yang } \\
\text { bertentangan dengan kearifan lokal (budaya setempat) }\end{array}$ \\
\hline & $\begin{array}{l}\text { c. Pertentangan dengan } \\
\text { peraturan setempat }\end{array}$ & $\begin{array}{l}\text { Ada tidaknya penggunaan jenis multigear yang } \\
\text { bertentangan dengan peraturan yang berlaku }\end{array}$ \\
\hline \multicolumn{3}{|c|}{ 4. Data aspek biologi: } \\
\hline & $\begin{array}{l}\text { a. Jumlah spesies yang } \\
\text { tertangkap }\end{array}$ & $\begin{array}{l}\text { Jumlah spesies ikan target yang tertangkap oleh jenis } \\
\text { multigearyang digunakan }\end{array}$ \\
\hline & b. Waktu musim penangkapan & $\begin{array}{l}\text { Jangka waktu musim penangkapan berdasarkan jenis } \\
\text { multigear yang digunakan }\end{array}$ \\
\hline & $\begin{array}{l}\text { c. Persentase ikan target } \\
\text { terhadap hasil tangkapan }\end{array}$ & $\begin{array}{l}\text { Perbedaan jenis multigear yang digunakan berkaitan } \\
\text { dengan persentase ikan target terhadap total hasil } \\
\text { tangkapan }\end{array}$ \\
\hline
\end{tabular}

Populasi yang digunakan untuk pengambilan sampel ini adalah unit usaha perikanan tangkap skala kecil di Kecamatan Banyuasin II Kabupaten Banyuasin Sumatera Selatan. Berdasarkan hasil survei awal, jumlah populasi dalam penelitian ini sebanyak 853 unit. Banyaknya responden dihitung dengan menggunakan rumus Nomogram Harry King dengan selang kepercayaan $90 \%$. Me- ngacu pada rumus tersebut, jumlah responden yang diwawancara sebanyak $7 \%$ dari populasi yakni 59 responden dengan pembagian setiap wilayah seperti pada Tabel 2.

Seluruh data aspek produktivitas, aspek ekonomi, aspek sosial dan aspek biologi dari unit penangkapan skala kecil yang menggunakan jenis multigear yang sama, selanjutnya diolah dengan cara mengelom- 
Ipokkan dalam satu katagori dan diberi kode sebelum dilakukan proses tabulasi. Tabulasi dilakukan dengan cara menyusun dan menghitung data yang termasuk dalam satu katagori sehingga dapat disajikan dalam bentuk tabel yang lengkap dengan judul dan kolom-kolom berserta keterangan di dalamnya. Tabulasi dilakukan menggunakan bantuan perangkat lunak Excel.

Analisis data mencakup 4 aspek yaitu aspek ekonomi, produktivitas, biologi dan sosial. Kriteria penilaian dari masing-masing aspek sebagai berikut:

1. Analisis aspek ekonomi/finansial merupakan analisis untuk menentukan kelayakan usaha yang dijalankan, meliputi; a) investasi, b) keuntungan, c) payback period, d) revenue cost ratio, e) dan pendapatan kotor (Rahmi et al. 2013; Wiyono 2011).

2. Analisis aspek produktivitas merupakan analisis untuk menggambarkan perbandingan output (jumlah hasil tangkapan dari unit penangkapan yang menggunakan jenis multigear tertentu dalam dalam kurun waktu tertentu) terhadap jenis input yang digunakan (GT kapal, daya mesin, dan jumlah nelayan), meliputi; a) hasil tangkapan/GT kapal, b) hasil tangkapan/daya mesin dan c) hasil tangkapan/jumlah nelayan (Rahmi et al. 2013; Rosalina 2011).

3. Analisis aspek sosial merupakan analisis untuk mengkaji kondisi kehidupan sosial nelayan (Rahmi et al. 2013), meliputi: a) konflik antar nelayan, b) pertentangan dengan budaya setempat, dan c) pertentangan dengan peraturan setempat.

4. Analisis aspek biologi merupakan analisis untuk menggambarkan jenis multigear yang digunakan untuk memanfaatkan sumberdaya ikan (Wiyono
2011). Dalam penelitian ini, penilaian penggunaan multigear pada unit penangkapan skala kecil dititikberatkan pada 3 kriteria, yaitu; a) jumlah spesies yang tertangkap, b) lama musim penangkapan dalam setahun, dan c) persentase berat ikan target terhadap rata-rata berat total hasil tangkapan per trip.

Menurut Wiyono (2011), analisis untuk menentukan tingkat keunggulan alat tangkap dapat menggunakan analisis kriteria ganda (multi-criteria analysis; MCA). Pada analisis MCA ini akan dilakukan standarisasi fungsi nilai dari semua kriteria aspek ekonomi (5 kriteria), produktivitas (3 kriteria), sosial (3 kriteria) dan biologi (3 kriteria) sehingga semua nilai memiliki standar yang sama. Penentuan urutan prioritas dari jenis multigear yang dipilih dengan menggunakan fungsi nilai ditetapkan secara urut dari alternatif yang memiliki fungsi nilai tertinggi ke alternatif fungsi nilai terendah.

Nilai setiap kriteria dalam penelitian ini tidak semua mencerminkan nilai tertinggi sebagai nilai terbaik (urutan prioritas pertama) tetapi ada yang sebaliknya (seperti payback period) dimana fungsi nilai terendah mencerminkan nilai terbaik. Oleh karena itu, rumus standarisasi fungsi nilai dari Iskandar dan Guntur (2014) harus dilakukan modifikasi sebagai berikut:

1. Rumus fungsi nilai untuk nilai variabel $X$ tertinggi sebagai nilai terbaik:

$$
V(X)=\frac{X-X_{0}}{X_{a}-X_{0}}
$$

2. Rumus fungsi nilai untuk nilai variabel $X$ terendah sebagai nilai terbaik:

$$
V(X)=\frac{X_{a}-X}{X_{a}-X_{0}}
$$

Tabel 2 Jumlah responden usaha perikanan tangkap skala kecil di Kecamatan Banyuasin II Kabupaten Banyuasin

\begin{tabular}{llcc}
\hline No & \multicolumn{1}{c}{ Wilayah } & $\begin{array}{c}\text { Populasi Usaha Perikanan } \\
\text { Tangkap Skala Kecil (unit) }\end{array}$ & $\begin{array}{c}\text { Jumlah } \\
\text { Responden }\end{array}$ \\
\hline 1 & Marga Sungsang & 129 & 9 \\
2 & Sungsang 1 & 203 & 14 \\
3 & Sungsang 2 & 202 & 14 \\
4 & Sungsang 3 & 192 & 13 \\
5 & Sungsang 4 & 127 & 9 \\
\hline \multicolumn{2}{l}{ Total } & $\mathbf{8 5 3}$ & $\mathbf{5 9}$ \\
\hline
\end{tabular}

Keterangan: Data didapat dari Sekdes/RT/Tokoh masyarakat setempat 
3. Perhitungan fungsi nilai alternatif untuk pengambilan keputusan:

$V(A)=\sum_{i=a}^{n} V i(X i)$

$i=a, b, c, d \ldots \ldots n$

dengan:

$V(X)=$ Fungsi nilai dari kriteria $\mathrm{X}$

$X \quad=$ Nilai variabel $X$

$\mathrm{Xa}=$ Nilai tertinggi pada kriteria $\mathrm{X}$

$X_{0}=$ Nilai terendah pada kriteria $X$

$V(A)=$ Fungsi nilai dari alternatif $\mathrm{A}$

$V 1(X i)=$ Fungsi nilai dari alternatif pada kriteria ke-i

4. Perhitungan total fungsi nilai alternatif:

$V(G)=\sum_{i=a}^{n} V(A)$

$i=a, b, c, d \ldots \ldots n$

dengan:

$V(G)=$ Fungsi nilai gabungaan dari alternatif $A$

$V(A)=$ Fungsi nilai dari alternatif $\mathrm{A}$

$V 1\left(X_{i}\right)=$ Fungsi nilai dari alternatif pada kriteria ke-i

$a, b, c . . . n=$ Aspek dari alternatif $A$

Howara dan Laapo (2008) menyatakan bahwa $V$ merupakan fungsi nilai yang mencerminkan preferensi pengambilan keputusan, maka alternatif yang terbaik adalah alternatif yang memberikan nilai $V(X)$ tertinggi.

5. Penilaian tingkat kinerja jenis multigear:

$K(A)=\frac{V(G)}{S} x 100 \%$

dengan:

$K(A)=$ Tingkat Kinerja dari alternatif $A$

$V(G)=$ Fungsi nilai gabungaan dari alternatif $A$

$S=$ Jumlah seluruh kriteria dari seluruh aspek

Dalam penelitian ini, nilai $K(A)$ yang mencerminkan tingkat kinerja jenis multigear akan diklasifikasikan sebagaimana disajikan pada Tabel 3. Tingkat kinerja alat tangkap diklasifikasikan dalam 3 katagori yaitu: layak, kurang layak dan tidak layak.

6. Penilaian jenis multigear unggulan yang layak dikembangkan:

Penilaian jenis multigear unggulan yang layak dikembangkan ditentukan berdasarkan kriteria sebagai berikut: a. Jenis multigear yang memiliki tingkat kinerja layak (Tabel 3)

b. Jenis multigear yang diguna-kan tidak terdapat jenis trawl, karena trawl telah dilarang oleh pemerintah.

\section{HASIL}

\section{Jenis Alat Tangkap}

Berdasarkan hasil wawancara kepada 59 nelayan yang menjadi responden penelitian, diperoleh 11 jenis multigear (Tabel 4). Berdasarkan Tabel 4 diketahui bahwa jenis jaring insang hanyut dengan mata jaring (mesh size) 2 inci paling banyak dikombinasikan dengan jenis alat tangkap lainnya.

Jenis multigear dioperasikan oleh nelayan kecil di Perairan Sungsang menggunakan ukuran kapal yang bervariasi. Tabel 5 menunjukkan spesifikasi kapal 1-5 GT pada usaha perikanan tangkap skala kecil yang menggunakan multigear. Semakin besar GT kapal, spesifikasi dimensi ukuran kapal semakin besar. Pada kapal 5 GT memiliki memiliki panjang total $15,35 \mathrm{~m}$, sedangkan kapal 1 GT memiliki panjang total 7,45 m.

Terdapat Dalam penelitian ini, definisi multigear adalah 2 jenis alat tangkap atau lebih yang dioperasikan dalam satu kapal. Single gear adalah alat tangkap dianggap satu jenis jika alat tangkap tersebut dioperasikan dengan metode yang sama, memiliki ukuran mata jaring yang sama dan ikan targetnya juga sama. Jenis multigear yang digunakan sebagian besar hanya kombinasi dari 2 jenis single gear. Jaring insang hanyut dengan mesh size 2 inci (Gambar 2) banyak dikombinasikan dengan alat tangkap lain yaitu jaring insang hanyut dengan mesh size 7 inci, jaring insang tetap, serok, trawl, trammel net, dan rawai hanyut. Adapun jaring insang hanyut dengan mesh size 3 inci hanya dikombinasikan dengan 3 jenis alat tangkap saja yaitu trawl, trammel net dan rawai hanyut.

Berdasarkan hasil wawancara, jenis multigear yang digunakan oleh nelayan sebagian besar bertujuan untuk meningkatkan hasil tangkapan karena target spesiesnya menjadi lebih banyak. Saldana et al. (2017) menjelaskan bahwa tidak hanya faktor ekonomi dan ketrampilan yang menentukan perubahan target spesies, namun juga ketersediaan spesies tersebut di wilayah pe- 
Tabel 3 Penilaian tingkat kinerja jenis multi-gear

\begin{tabular}{cc}
\hline Nilai kinerja & Kategori \\
\hline $66<\mathrm{K}(\mathrm{A}) \leq 100$ & Layak \\
$33<\mathrm{K}(\mathrm{A}) \leq 66$ & Kurang layak \\
$0 \leq \mathrm{K}(\mathrm{A}) \leq 33$ & Tidak layak \\
\hline
\end{tabular}

Tabel 4 Jenis multigear yang digunakan pada usaha perikanan tangkap skala kecil di Perairan Sungsang

\begin{tabular}{ll}
\hline No & \multicolumn{1}{c}{ Jenis multigear yang digunakan pada usaha perikanan tangkap skala kecil } \\
\hline 1. & Trawl, Jaring Udang, Rawai Hanyut (Umpan) \\
2. & Jaring Insang Hanyut (mesh, 2 inci), Trawl \\
3. & Jaring Insang Hanyut (mesh, 7 inci), Jaring Insang Hanyut (mesh, 2 inci) \\
4. & Jaring Insang Hanyut (mesh, 2 inci), Jaring Udang \\
5. & Jaring Udang, Rawai Hanyut (Umpan) \\
6. & Jaring Insang Hanyut (mesh, 2 inci), Jaring Insang Tetap \\
7. & Jaring Insang Hanyut (mesh, 3 inci), Jaring Udang \\
8. & Serok, Jaring Insang Hanyut (mesh, 2 inci) \\
9. & Jaring Insang Hanyut (mesh, 3 inci), Rawai Hanyut (Umpan) \\
10. & Jaring Insang Hanyut (mesh, 3 inci), Trawl \\
11. & Rawai Hanyut (Umpan), Jaring Insang Hanyut (mesh, 2 inci) \\
\hline
\end{tabular}

Tabel 5 Spesifikasi kapal perikanan tangkap kecil di Desa Sungsang

\begin{tabular}{|c|c|c|c|c|c|}
\hline \multicolumn{6}{|c|}{ Spesifikasi kapal perikanan tangkap kecil } \\
\hline Tonnase (GT) & $\begin{array}{c}\text { LOA } \\
(\mathrm{m})\end{array}$ & $\begin{array}{l}\text { Lpp } \\
\text { (m) }\end{array}$ & $\begin{array}{c}\text { Breadth } \\
\text { (m) }\end{array}$ & $\begin{array}{c}\text { Depth } \\
(\mathrm{m})\end{array}$ & $\begin{array}{c}\text { draft } \\
(\mathrm{m})\end{array}$ \\
\hline 1 & 7,45 & 6,80 & 1,16 & 0,35 & 0,2 \\
\hline 2 & 11 & 9 & 1,60 & 0,70 & 0,4 \\
\hline 3 & 13 & 11 & 2,20 & 0,80 & 0,5 \\
\hline 5 & 15,35 & 13 & 2,30 & 1,20 & 0,6 \\
\hline
\end{tabular}

\section{Keterangan:}

GT : Gross Tonnage

LOA : Panjang Seluruh kapal

Lpp : : Panjang Garis Tegak kapal

nangkapan dan kondisi lingkungan. Perubahan target spesies juga dilakukan oleh nelayan luar negeri, misalnya Ikaragua, Kolombia dan beberapa Kepulauan Karibia (Béné dan Tewfik 2001; Pet-Soede et al. 2001; Daw 2008; Maynou et al. 2011; TorresGuevara et al. 2016). Penggunaan multigear juga telah dilakukan oleh nelayan di wilayah lain di Indonesia, misalnya di Kendal dan Gunung Kidul. Penggunaan multigear tersebut dioperasikan pada musim yang berbeda dan dapat menghasilkan banyak jenis hasil tangkapan (Koeshendrajana et al. 2012; Wahyuningrum et al. 2012; Wismaningrum et al. 2013; Yanuartono et al. 2011).

\section{Penilaian Jenis Multigear}

Penilaian jenis multigear yang digunakan pada usaha perikanan tangkap skala kecil di Kabupaten Banyuasin berdasarkan pada kriteria-kriteria dari 4 aspek ya-
Breadth : Lebar

Depth : Tinggi

draft : Sarat Tinggi Air

itu: aspek ekonomi, produktivitas, sosial dan biologi. Hasil penilaian kriteria aspek ekonomi (Tabel 6) menunjukkan bahwa jenis multigear dengan kombinasi alat tangkap trawl, jaring udang, rawai hanyut (umpan) menempati prioritas pertama. Jenis multigear tersebut memiliki kriteria nilai keuntungan dan payback period terbaik, sedangkan kriteria nilai investasi, revenue cost ratio dan payback period bukan yang terbaik jika dibandingkan dengan jenis lainnya. Namun demikian, secara akumulatif, jumlah nilai dari kelima kriteria pada aspek ekonomi memiliki nilai tertinggi yaitu 4,21 . Hal ini menunjukkan bahwa kombinasi alat tangkap trawl, jaring udang, rawai hanyut (umpan) merupakan jenis multigear yang terbaik berdasarkan aspek ekonomi.

Hasil penilaian kriteria aspek produktivitas (Tabel 7) menunjukkan bahwa jenis multigear dengan kombinasi antara 
trawl, jaring udang dan rawai hanyut merupakan jenis multigear terbaik dengan fungsi nilai aspek produktivitas sebesar 3,000. Jenis multigear tersebut memiliki nilai tertinggi pada setiap kriteria pada aspek produktivitas yaitu hasil tangkapan per trip/GT kapal, hasil tangkapan per trip/nelayan maupun hasil tangkapan per trip/daya mesin kapal.

Hasil penilaian kriteria aspek sosial (Tabel 8) menunjukkan bahwa sebagian besar jenis multigear memiliki nilai tertinggi pada 3 kriteria yaitu: konflik antar nelayan, pertentangan dengan budaya setempat, dan pertentangan dengan peraturan setempat. Artinya, penggunaan jenis multigear tersebut tidak menimbulkan konflik antar nelayan maupun pertentangan dengan budaya setempat dan peraturan setempat. Sebaliknya, setiap jenis multigear yang salah satunya gabungan dari trawl akan memperoleh nilai terendah.

Hasil berbeda ditunjukkan pada penilaian kriteria aspek biologi (Tabel 9) dimana kombinasi jaring insang hanyut (mesh, 3 inci) dan rawai hanyut merupakan jenis multigear terbaik dengan total nilai 3 . Jenis multigear ini memiliki nilai tertinggi pada seluruh aspek biologi yaitu: lama musim penangkapan, persentase ikan target, dan jumlah spesies yang tertangkap. Kombinasi jaring udang dan rawai hanyut yang sebelumnya menempati urutan prioritas pertama berdasarkan penilaian aspek sosial, pada penilaian aspek biologi ini hanya menempati urutan prioritas ke-9.

Berdasarkan Tabel 10, terdapat 3 jenis multigear yang memiliki kinerja layak (66 < $(\mathrm{K}(\mathrm{A}) \leq 100), 6$ jenis multigear memiliki kinerja kurang layak $(33<(\mathrm{K}(\mathrm{A}) \leq 66)$, dan 2 jenis multigear memiliki kinerja tidak layak ( 0 $<(K(A) \leq 33)$. Jenis multigear dengan nilai kinerja yang layak adalah: 1) kombinasi jaring udang dengan rawai hanyut; 2) kombinasi jaring insang hanyut (mesh 3 inci) dengan rawai hanyut (umpan); dan 3) kombinasi jaring insang hanyut (mesh 2 inci) dengan jaring udang. Sebaliknya, jenis multigear dengan kombinasi jaring insang hanyut (mesh, 2 inci) dengan trawl dan kombinasi jaring in-sang hanyut (mesh 3 inci) dengan trawl merupakan jenis multigear yang memiliki kinerja tidak layak.

\section{Penilaian Jenis Multigear}

Penilaian jenis multigear yang digunakan pada usaha perikanan tangkap skala kecil di Kabupaten Banyuasin berda- sarkan pada kriteria-kriteria dari 4 aspek yaitu: aspek ekonomi, produktivitas, sosial dan biologi. Hasil penilaian kriteria aspek ekonomi (Tabel 6) menunjukkan bahwa jenis multigear dengan kombinasi alat tangkap trawl, jaring udang, rawai hanyut (umpan) menempati prioritas pertama. Jenis multigear tersebut memiliki kriteria nilai keuntungan dan payback period terbaik, sedangkan kriteria nilai investasi, revenue cost ratio dan payback period bukan yang terbaik jika dibandingkan dengan jenis lainnya. Namun demikian, secara akumulatif, jumlah nilai dari kelima kriteria pada aspek ekonomi memiliki nilai tertinggi yaitu 4,21 . Hal ini menunjukkan bahwa kombinasi alat tangkap trawl, jaring udang, rawai hanyut (umpan) merupakan jenis multigear yang terbaik berdasarkan aspek ekonomi.

Hasil penilaian kriteria aspek produktivitas (Tabel 7) menunjukkan bahwa jenis multigear dengan kombinasi antara trawl, jaring udang dan rawai hanyut merupakan jenis multigear terbaik dengan fungsi nilai aspek produktivitas sebesar 3,000. Jenis multigear tersebut memiliki nilai tertinggi pada setiap kriteria pada aspek produktivitas yaitu hasil tangkapan per trip/GT kapal, hasil tangkapan per trip/nelayan maupun hasil tangkapan per trip/daya mesin kapal.

Hasil penilaian kriteria aspek sosial (Tabel 8) menunjukkan bahwa sebagan besar jenis multigear memiliki nilai tertinggi pada 3 kriteria yaitu: konflik antar nelayan, pertentangan dengan budaya setempat, dan pertentangan dengan peraturan setempat. Artinya, penggunaan jenis multigear tersebut tidak menimbulkan konflik antar nelayan maupun pertentangan dengan budaya setempat dan peraturan setempat. Sebaliknya, setiap jenis multigear yang salah satunya gabungan dari trawl akan memperoleh nilai terendah.

Hasil berbeda ditunjukkan pada penilaian kriteria aspek biologi (Tabel 9) dimana kombinasi jaring insang hanyut (mesh, 3 inci) dan rawai hanyut merupakan jenis multigear terbaik dengan total nilai 3 . Jenis multigear ini memiliki nilai tertinggi pada seluruh aspek biologi yaitu: lama musim penangkapan, persentase ikan target, dan jumlah spesies yang tertangkap. Kombinasi jaring udang dan rawai hanyut yang sebelumnya menempati urutan prioritas pertama berdasarkan penilaian aspek sosial, pada penilaian aspek biologi ini hanya menempati urutan prioritas ke-9. 
Berdasarkan Tabel 10, terdapat 3 jenis multigear yang memiliki kinerja layak $(66<$ $(\mathrm{K}(\mathrm{A}) \leq 100), 6$ jenis multigear memiliki kinerja kurang layak $(33<(K(A) \leq 66)$, dan 2 jenis multigear memiliki kinerja tidak layak $(0$ $<(K(A) \leq 33)$. Jenis multigear dengan nilai kinerja yang layak adalah: 1) kombinasi jaring udang dengan rawai hanyut; 2) kombinasi jaring insang hanyut (mesh 3 inci) dengan ra- wai hanyut (umpan); dan 3) kombinasi jaring insang hanyut (mesh 2 inci) dengan jaring udang. Sebaliknya, jenis multigear dengan kombinasi jaring insang hanyut (mesh, 2 inci) dengan trawl dan kombinasi jaring in-sang hanyut (mesh 3 inci) dengan trawl merupakan jenis multigear yang memiliki kinerja tidak layak.
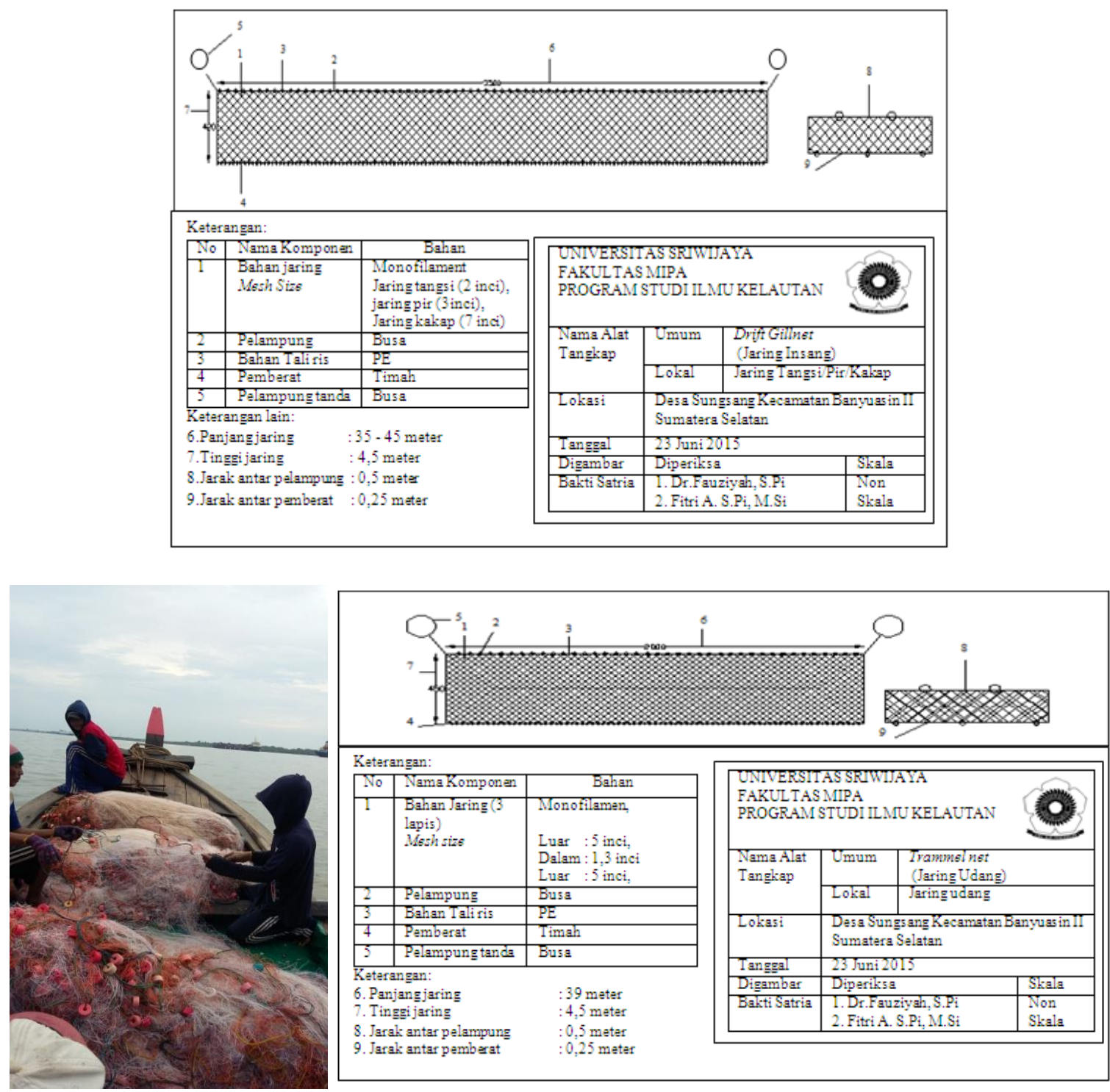

Gambar 2 Alat tangkap jaring insang hanyut dan jaring udang di perairan Sungsang Kecamatan Banyuasin II Sumatera Selatan 
Tabel 6 Penilaian jenis muligears pada usaha perikanan tangkap skala kecil di Kecamatan Banyuasin II berdasarkan kriteria aspek ekonomi

\begin{tabular}{|c|c|c|c|c|c|c|c|c|c|c|c|c|c|}
\hline No & Alat tangkap & $X_{1}$ & $\mathrm{X}_{1} \mathrm{~V}_{1}$ & $X_{2}$ & $X_{2} V_{2}$ & $X_{3}$ & $X_{3} V_{3}$ & $\mathbf{X}_{4}$ & $\mathrm{X}_{4} \mathrm{~V}_{4}$ & $X_{5}$ & $X_{5} V_{5}$ & $V(A)$ & UP \\
\hline 1 & $\begin{array}{l}\text { Trawl, Jaring Udang, } \\
\text { Rawai Hanyut } \\
\text { (Umpan) }\end{array}$ & 66.825 .000 & 0,65 & 122.065 .000 & 1,00 & 0,55 & 1,00 & 1,39 & 0,65 & 436.800 .000 & 0,82 & 4,12 & 1 \\
\hline 2 & $\begin{array}{l}\text { Jaring Insang Hanyut } \\
\text { (mesh, } 2 \text { inci), Trawl }\end{array}$ & 57.050 .000 & 0,77 & 90.053 .143 & 0,68 & 0,63 & 0,97 & 1,52 & 1,00 & 264.585 .000 & 0,27 & 3,70 & 2 \\
\hline 3 & $\begin{array}{l}\text { Jaring Insang Hanyut } \\
\text { (mesh, } 7 \text { inci), Jaring } \\
\text { Insang Hanyut } \\
\text { (mesh, } 2 \text { inci) }\end{array}$ & 63.400 .000 & 0,69 & 90.629 .286 & 0,68 & 0,70 & 0,94 & 1,32 & 0,46 & 375.450 .000 & 0,63 & 3,41 & 3 \\
\hline 4 & $\begin{array}{l}\text { Jaring Insang Hanyut } \\
\text { (mesh, } 2 \text { inci), Jaring } \\
\text { Udang }\end{array}$ & 57.931 .250 & 0,76 & 91.313 .917 & 0,69 & 0,63 & 0,97 & 1,30 & 0,41 & 262.950 .000 & 0,27 & 3,10 & 4 \\
\hline 5 & $\begin{array}{l}\text { Jaring Udang, Rawai } \\
\text { Hanyut (Umpan) }\end{array}$ & 113.600 .000 & 0,05 & 108.903.334 & 0,87 & 1,04 & 0,82 & 1,28 & 0,35 & 492.300 .000 & 1,00 & 3,09 & 5 \\
\hline 6 & $\begin{array}{l}\text { Jaring Insang Hanyut } \\
\text { (mesh, } 2 \text { inci), Jaring } \\
\text { Insang Tetap }\end{array}$ & 48.400 .000 & 0,88 & 55.392 .500 & 0,33 & 0,87 & 0,88 & 1,28 & 0,35 & 253.770.000 & 0,24 & 2,69 & 6 \\
\hline 7 & $\begin{array}{l}\text { Jaring Insang Hanyut } \\
\text { (mesh, } 3 \text { inci), Jaring } \\
\text { Udang }\end{array}$ & 82.550 .000 & 0,45 & 72.830 .000 & 0,50 & 1,13 & 0,79 & 1,36 & 0,57 & 273.960.000 & 0,30 & 2,61 & 7 \\
\hline 8 & $\begin{array}{l}\text { Serok, Jaring Insang } \\
\text { Hanyut (mesh, } 2 \text { inci) }\end{array}$ & 65.750 .000 & 0,66 & 37.300 .000 & 0,15 & 1,76 & 0,55 & 1,18 & 0,08 & 250.140 .000 & 0,23 & 1,67 & 8 \\
\hline 9 & $\begin{array}{l}\text { Jaring Insang Hanyut } \\
\text { (mesh, } 3 \text { inci), Rawai } \\
\text { Hanyut (Umpan) }\end{array}$ & 39.275 .000 & 1,00 & 22.741 .667 & 0,00 & 1,73 & 0,56 & 1,15 & 0,00 & 178.560 .000 & 0,00 & 1,56 & 9 \\
\hline 10 & $\begin{array}{l}\text { Jaring Insang Hanyut } \\
\text { (mesh, } 3 \text { inci), Trawl }\end{array}$ & 96.925 .000 & 0,26 & 34.246 .667 & 0,12 & 2,83 & 0,16 & 1,15 & 0,00 & 262.950 .000 & 0,27 & 0,81 & 10 \\
\hline 11 & $\begin{array}{l}\text { Rawai Hanyut } \\
\text { (Umpan), Jaring } \\
\text { Insang Hanyut } \\
\text { (mesh, } 2 \text { inci) }\end{array}$ & 117.500 .000 & 0,00 & 36.015 .667 & 0,13 & 3,26 & 0,00 & 1,20 & 0,14 & 220.608 .000 & 0,13 & 0,40 & 11 \\
\hline
\end{tabular}

Keterangan:

$\mathrm{X}_{1}$ : Investasi $(\mathrm{Rp})$

UP: Urutan Prioritas $\mathrm{X}_{2}$ : Keuntungan Pemilik (Rp)

$\mathrm{X}_{4}$ : Revenue cost ratio

$\mathrm{X}_{3}$ : Payback period

$\mathrm{X}_{5}$ : Pendapatan kotor $(\mathrm{Rp})$

$V(A)$ : Fungsi Nilai Alternatif $A$ 
Tabel 7 Penilaian jenis multigears pada usaha perikanan tangkap skala kecil di Kecamatan Banyuasin II berdasarkan kriteria aspek produktivitas

\begin{tabular}{|c|c|c|c|c|c|c|c|c|c|}
\hline No & Jenis Multigear & $X_{1}$ & $X_{1} V_{1}$ & $X_{2}$ & $X_{2} V_{2}$ & $X_{3}$ & $X_{3} V_{3}$ & $X_{4}$ & $X_{4} V_{4}$ \\
\hline 1 & $\begin{array}{l}\text { Trawl, jaring udang, rawai } \\
\text { hanyut }\end{array}$ & 160,420 & 1,000 & 96,250 & 1,000 & 20,050 & 1,000 & 3,000 & 1 \\
\hline 2 & Jaring udang, rawai hanyut & 114,330 & 0,685 & 85,750 & 0,876 & 14,290 & 0,687 & 2,249 & 2 \\
\hline 3 & $\begin{array}{l}\text { Jaring insang hanyut (mesh, } 2 \\
\text { inci), trawl }\end{array}$ & 67,480 & 0,364 & 44,980 & 0,397 & 5,620 & 0,217 & 0,978 & 3 \\
\hline 4 & $\begin{array}{l}\text { Jaring insang hanyut (mesh, } 2 \\
\text { inci), jaring udang }\end{array}$ & 48,520 & 0,235 & 48,520 & 0,438 & 6,570 & 0,268 & 0,941 & 4 \\
\hline 5 & $\begin{array}{l}\text { Jaring insang hanyut (mesh, } 3 \\
\text { inci), rawai hanyut }\end{array}$ & 55,420 & 0,282 & 41,560 & 0,356 & 6,930 & 0,288 & 0,926 & 5 \\
\hline 6 & $\begin{array}{l}\text { Rawai hanyut, jaring insang } \\
\text { hanyut (mesh, } 2 \text { inci) }\end{array}$ & 37,200 & 0,157 & 41,850 & 0,360 & 7,610 & 0,325 & 0,842 & 6 \\
\hline 7 & $\begin{array}{l}\text { Serok, jaring insang hanyut } \\
\text { (mesh, } 2 \text { inci) }\end{array}$ & 43,030 & 0,197 & 32,270 & 0,247 & 4,610 & 0,162 & 0,606 & 7 \\
\hline 8 & $\begin{array}{l}\text { Jaring insang hanyut (mesh, } 3 \\
\text { inci), jaring udang }\end{array}$ & 37,330 & 0,158 & 28,000 & 0,197 & 4,670 & 0,165 & 0,520 & 8 \\
\hline 9 & $\begin{array}{l}\text { Jaring insang hanyut (mesh, } 7 \\
\text { inci), jaring insang hanyut } \\
\text { (mesh, } 2 \text { inci) }\end{array}$ & 26,080 & 0,081 & 32,600 & 0,251 & 1,630 & 0,000 & 0,332 & 9 \\
\hline 10 & $\begin{array}{l}\text { Jaring insang hanyut (mesh, } 3 \\
\text { inci), trawl }\end{array}$ & 14,200 & 0,000 & 23,670 & 0,146 & 2,960 & 0,072 & 0,218 & 10 \\
\hline 11 & $\begin{array}{l}\text { Jaring insang hanyut (mesh, } 2 \\
\text { inci), jaring insang tetap }\end{array}$ & 14,510 & 0,002 & 11,280 & 0,000 & 2,120 & 0,027 & 0,029 & 11 \\
\hline
\end{tabular}

Keterangan:

$\mathrm{X}_{1}$ : Hasil tangkapan per trip/GT kapal $(\mathrm{kg} / \mathrm{GT}) \quad \mathrm{V}(\mathrm{A})$ : Fungsi Nilai Alternatif A

$\mathrm{X}_{2}$ : Hasil tangkapan per trip/nelayan $(\mathrm{kg} / \mathrm{org}) \quad$ UP : Urutan Prioritas

$\mathrm{X}_{3}$ : Hasil tangkapan per trip/daya mesin $(\mathrm{kg} / \mathrm{PK})$

Tabel 8 Penilaian jenis multigear pada usaha perikanan tangkap skala kecil di Kecamatan Banyuasin II berdasarkan kriteria aspek sosial

\begin{tabular}{|c|c|c|c|c|c|c|c|c|c|}
\hline No & Jenis Multigear & $X_{1}$ & $\mathrm{X}_{1} \mathrm{~V}_{1}$ & $X_{2}$ & $\mathrm{X}_{2} \mathrm{~V}_{2}$ & $\mathbf{X}_{3}$ & $\mathrm{X}_{3} \mathrm{~V}_{3}$ & $V(A)$ & UP \\
\hline 1 & Jaring udang, rawai hanyut & 2 & 1 & 2 & 1 & 2 & 1 & 3 & 1 \\
\hline 2 & $\begin{array}{l}\text { Jaring insang hanyut (mesh, } 2 \\
\text { inci), jaring udang }\end{array}$ & 2 & 1 & 2 & 1 & 2 & 1 & 3 & 1 \\
\hline 3 & $\begin{array}{l}\text { Jaring insang hanyut (mesh, } 7 \\
\text { inci), jaring insang hanyut (mesh, } \\
2 \text { inci) }\end{array}$ & 2 & 1 & 2 & 1 & 2 & 1 & 3 & 1 \\
\hline 4 & $\begin{array}{l}\text { Jaring insang hanyut (mesh, } 3 \\
\text { inci), jaring udang }\end{array}$ & 2 & 1 & 2 & 1 & 2 & 1 & 3 & 1 \\
\hline 5 & $\begin{array}{l}\text { Jaring insang hanyut (mesh, } 2 \\
\text { inci), jaring insang tetap }\end{array}$ & 2 & 1 & 2 & 1 & 2 & 1 & 3 & 1 \\
\hline 6 & $\begin{array}{l}\text { Serok, jaring insang hanyut } \\
\text { (mesh, } 2 \text { inci) }\end{array}$ & 2 & 1 & 2 & 1 & 2 & 1 & 3 & 1 \\
\hline 7 & $\begin{array}{l}\text { Rawai hanyut, jaring insang } \\
\text { hanyut (mesh, } 2 \text { inci) }\end{array}$ & 2 & 1 & 2 & 1 & 2 & 1 & 3 & 1 \\
\hline 8 & $\begin{array}{l}\text { Jaring insang hanyut (mesh, } 3 \\
\text { inci), rawai hanyut }\end{array}$ & 2 & 1 & 2 & 1 & 2 & 1 & 3 & 1 \\
\hline 9 & Trawl, jaring udang, rawai hanyut & 1 & 0 & 1 & 0 & 1 & 0 & 0 & 2 \\
\hline 10 & $\begin{array}{l}\text { Jaring insang hanyut (mesh, } 2 \\
\text { inci), trawl }\end{array}$ & 1 & 0 & 1 & 0 & 1 & 0 & 0 & 2 \\
\hline 11 & $\begin{array}{l}\text { Jaring insang hanyut (mesh, } 3 \\
\text { inci), trawl }\end{array}$ & 1 & 0 & 1 & 0 & 1 & 0 & 0 & 2 \\
\hline $\begin{array}{l}\text { Ketera } \\
X_{1}: \text { Kol } \\
X_{2}: \text { Pel } \\
X_{3}: \text { Pel }\end{array}$ & $\begin{array}{l}\text { lik: } \\
\text { lik antar nelayan } \\
\text { entangan dengan budaya setempat } \\
\text { entangan dengan peraturan setempat }\end{array}$ & & $\begin{array}{l}: \text { Fun } \\
: \text { Uru }\end{array}$ & $\begin{array}{ll}\text { Jilai } A \\
\text { Priorit }\end{array}$ & latif $A$ & & & & \\
\hline
\end{tabular}


Tabel 9 Penilaian jenis multigear pada usaha perikanan tangkap skala kecil di Kecamatan Banyuasin II berdasarkan kriteria aspek biologi

\begin{tabular}{|c|c|c|c|c|c|c|c|c|c|}
\hline No & Alat Tangkap Multigear & $X_{1}$ & $\mathrm{X}_{1} \mathrm{~V}_{1}$ & $X_{2}$ & $X_{2} V_{2}$ & $\mathbf{X}_{3}$ & $\mathrm{X}_{3} \mathrm{~V}_{3}$ & $V(A)$ & UP \\
\hline 1 & $\begin{array}{l}\text { Jaring insang hanyut (mesh, } 3 \\
\text { inci), rawai hanyut }\end{array}$ & 6 & 1 & 100 & 1,000 & 3 & 1,000 & 3,000 & 1 \\
\hline 2 & $\begin{array}{l}\text { Jaring insang hanyut (mesh, } 3 \\
\text { inci), trawl }\end{array}$ & 6 & 1 & 73 & 0,156 & 3 & 1,000 & 2,156 & 2 \\
\hline 3 & $\begin{array}{l}\text { Jaring insang hanyut (mesh, } 3 \\
\text { inci), jaring udang }\end{array}$ & 6 & 1 & 75 & 0,211 & 4 & 0,900 & 2,111 & 3 \\
\hline 4 & $\begin{array}{l}\text { Jaring insang hanyut (mesh, } 2 \\
\text { inci), jaring udang }\end{array}$ & 6 & 1 & 83 & 0,454 & 7 & 0,600 & 2,054 & 4 \\
\hline 5 & $\begin{array}{l}\text { Jaring insang hanyut (mesh, } 7 \\
\text { inci), jaring insang hanyut (mesh, } \\
2 \text { inci) }\end{array}$ & 6 & 1 & 76 & 0,254 & 5 & 0,800 & 2,054 & 5 \\
\hline 6 & $\begin{array}{l}\text { Serok, jaring insang hanyut } \\
\text { (mesh, } 2 \text { inci) }\end{array}$ & 6 & 1 & 68 & 0,000 & 3 & 1,000 & 2,000 & 6 \\
\hline 7 & $\begin{array}{l}\text { Rawai hanyut, jaring insang } \\
\text { hanyut (mesh, } 2 \text { inci) }\end{array}$ & 6 & 1 & 75 & 0,203 & 7 & 0,600 & 1,803 & 7 \\
\hline 8 & $\begin{array}{l}\text { Jaring insang hanyut (mesh, } 2 \\
\text { inci), jaring insang tetap }\end{array}$ & 6 & 1 & 75 & 0,200 & 8 & 0,500 & 1,700 & 8 \\
\hline 9 & Jaring udang, rawai hanyut & 6 & 1 & 76 & 0,236 & 9 & 0,400 & 1,636 & 9 \\
\hline 10 & Trawl, jaring udang, rawai hanyut & 6 & 1 & 78 & 0,320 & 10 & 0,300 & 1,620 & 10 \\
\hline 11 & $\begin{array}{l}\text { Jaring insang hanyut (mesh, } 2 \\
\text { inci), trawl }\end{array}$ & 6 & 1 & 69 & 0,035 & 13 & 0,000 & 1,035 & 11 \\
\hline \multicolumn{10}{|c|}{$\begin{array}{l}\text { Lama musim penangkapan ikan dalam s } \\
\text { Fungsi Nilai Alternatif } A \\
\text { Persentase berat ikan target dari rata-rat } \\
\text { Urutan Prioritas } \\
\text { Jumlah spesies yang tertangkap (jenis) }\end{array}$} \\
\hline
\end{tabular}

Tabel 10 Penilaian jenis multigear pada usaha perikanan tangkap skala kecil di Kecamatan Banyuasin II berdasarkan aspek ekonomi, produktivitas, sosial dan biologi

\begin{tabular}{|c|c|c|c|c|c|c|c|}
\hline No & Jenis Mulitgears & $V(A)_{1}$ & $V(A)_{2}$ & $\mathrm{~V}(\mathrm{~A})_{3}$ & $V(A)_{4}$ & $\mathbf{V}(\mathbf{G})$ & $K(A)$ \\
\hline 1. & Jaring udang, rawai hanyut (umpan) & 4,120 & 2,249 & 3 & 1,636 & 11,004 & $78,603^{L}$ \\
\hline 2. & $\begin{array}{l}\text { Jaring insang hanyut (mesh, } 3 \text { inci), } \\
\text { rawai hanyut (umpan) }\end{array}$ & 3,088 & 0,926 & 3 & 3,000 & 10,014 & $71,528^{L}$ \\
\hline 3. & $\begin{array}{l}\text { Jaring insang hanyut (mesh, } 2 \text { inci), } \\
\text { jaring udang }\end{array}$ & 3,695 & 0,941 & 3 & 2,054 & 9,691 & $69,219^{L}$ \\
\hline 4. & $\begin{array}{l}\text { Jaring insang hanyut (mesh, } 7 \text { inci), } \\
\text { Jaring insang hanyut (mesh, } 2 \text { inci) }\end{array}$ & 3,097 & 0,332 & 3 & 2,054 & 8,483 & $60,592 \mathrm{KL}$ \\
\hline 5. & $\begin{array}{l}\text { Jaring insang hanyut (mesh, } 3 \text { inci), } \\
\text { jaring udang }\end{array}$ & 2,685 & 0,520 & 3 & 2,111 & 8,316 & $59,401 \mathrm{KL}$ \\
\hline 6. & $\begin{array}{l}\text { Trawl, jaring udang, rawai hanyut } \\
\text { (umpan) }\end{array}$ & 3,407 & 3,000 & 0 & 1,620 & 8,026 & $57,332^{\mathrm{KL}}$ \\
\hline 7. & $\begin{array}{l}\text { Jaring insang hanyut (mesh, } 2 \text { inci), } \\
\text { jaring insang tetap }\end{array}$ & 2,609 & 0,029 & 3 & 1,700 & 7,337 & $52,408^{\mathrm{KL}}$ \\
\hline 8. & $\begin{array}{l}\text { Serok, jaring insang hanyut (mesh, } \\
2 \text { inci) }\end{array}$ & 671 & 0,606 & 3 & 2,000 & 7,277 & $51,977^{\mathrm{KL}}$ \\
\hline .9 & $\begin{array}{l}\text { Rawai hanyut (umpan), jaring } \\
\text { insang hanyut (mesh, } 2 \text { inci) }\end{array}$ & 0,807 & 0,842 & 3 & 1,803 & 6,451 & $46,077^{\mathrm{KL}}$ \\
\hline 10. & $\begin{array}{l}\text { Jaring insang hanyut (mesh, } 2 \text { inci), } \\
\text { trawl }\end{array}$ & 1,565 & 0,978 & 0 & 1,035 & 3,577 & $25,551^{\mathrm{TL}}$ \\
\hline 11. & $\begin{array}{l}\text { Jaring insang hanyut (mesh, } 3 \text { inci), } \\
\text { trawl }\end{array}$ & 0,403 & 0,218 & 0 & 2,156 & 2,776 & $19,831^{\mathrm{TL}}$ \\
\hline $\begin{array}{l}\text { Ketera } \\
\text { V(A)1: } \\
\text { V(A)2: } \\
\text { V(A)3: } \\
\text { V(A)4: } \\
\text { V(G) } t\end{array}$ & $\begin{array}{l}\text { gan: } \\
\text { ungsi nilai aspek ekonomi } \\
\text { ungsi nilai aspek produktivitas } \\
\text { ungsi nilai aspek sosial } \\
\text { ungsi nilai aspek bilologi } \\
\text { al: total fungsi nilai }\end{array}$ & \multicolumn{2}{|r|}{$\begin{array}{l}\mathrm{K}(\mathrm{A}) \\
\mathrm{L} \\
\mathrm{KL} \\
\mathrm{TL}\end{array}$} & \multicolumn{4}{|c|}{$\begin{array}{l}\text { : Tingkat kinerja alaternatif A } \\
\text { : Layak } \\
\text { : Kurang Layak } \\
\text { : Tidak Layak }\end{array}$} \\
\hline
\end{tabular}




\section{PEMBAHASAN}

Penilaian jenis multigear unggulan yang layak dikembangkan pada usaha perikanan tangkap skala kecil harus memenuhi 2 kriteria, yaitu: 1) jenis multigear yang digunakan memiliki kinerja yang layak, dan 2) jenis multigear yang digunakan tidak terdapat jenis trawl (alat tangkap yang dilarang). Berdasarkan kedua kriteria tersebut, jenis multigear unggulan yang layak dikembangkan, yaitu: 1) kombinasi jaring udang dengan rawai hanyut; 2) kombinasi jaring insang hanyut (mesh, 3 inci) dengan rawai hanyut (umpan); dan 3) kombinasi jaring insang hanyut (mesh, 2 inci) dengan jaring udang.

Banyaknya jenis multigear yang digunakan oleh nelayan Sungsang diduga terkait dengan masih tingginya potensi sumberdaya di perairan Banyuasin. Rosalina (2011) menjelaskan bahwa selain kaya akan sumberdaya ikan, perairan pantai Kabupaten Banyuasin juga kaya akan berbagai jenis udang terutama udang windu, jerbung, udang dogol, kepiting bakau serta kerang dan rajungan. Menurut Septifitri et al. (2010), komoditas unggulan perikanan tangkap di Sumatera Selatan adalah udang, rajungan, ikan manyung dan ikan golok-golok dengan tingkat pemanfaatan keempat komoditas unggulan tersebut masih dibawah $70 \%$.

Ketiga jenis multigear unggulan hasil analisis menunjukkan bahwa jenis mulitigear unggulan merupakan kombinasi dari 3 jenis single gear yaitu jaring insang hanyut (mesh 2 inci), jaring udang (trammel net) dan rawai hanyut. Jaring udang paling banyak dikombinasikan dengan alat tangkap lainnya. Artinya, jenis jaring udang menjadi single gear utama yang akan dikombinasikan dengan rawai hanyut atau jaring insang hanyut (mesh, 2 inci) untuk menghasilkan jenis multigear unggulan. Rawai hanyut dan jaring insang hanyut adalah alat tangkap yang dioperasikan dengan mengikuti arah arus dan biasanya untuk menangkap ikanikan pelagis. Wiyono (2011) menjelaskan bahwa jaring insang hanyut biasanya dioperasikan untuk menangkap jenis ikan pelagis dan kadang-kadang tertangkap juga jenis ikan dasar. Menurut Rosalina (2011), prioritas pengembangan alat tangkap untuk penangkapan ikan pelagis di Kabupaten Banyuasin adalah rawai hanyut, jaring insang hanyut dan bagan tancap.
Trammel net merupakan salah satu jenis alat tangkap yang digunakan untuk menangkap udang sebagai spesies target dan spesies non-target lainnya (Purbayanto 2005; Suharno et al. 2016; Sutriyono et al. 2017). Menurut Dwirasina dan Abidin (2013), trammel net juga dioperasikan nelayan di estuari Sungai Musi, Kabupaten Banyuasin. Septifitri at al. (2010) menegaskan bahwa jenis alat tangkap trammel net, jaring insang hanyut dan bagan tancap merupakan alat tangkap prioritas terbaik untuk dikembangkan di Provinsi Sumatera Selatan berdasarkan analisis dengan metode scoring dengan mempertimbangkan aspek biologi, teknis, sosial dan ekonomi. Menurut Harahap et al. (2000), berdasarkan aspek teknis, nilai efisiensi trammel net lebih tinggi bila dibandingkan alat tangkap lainnya karena alat tangkap ini hampir menangkap seluruh jenis ikan dasar dari berbagai ukuran. Namun di sisi lain, alat tangkap trammel net ini memiliki tingkat selektivitas yang rendah dan termasuk dalam katagori alat tangkap ikan yang kurang ramah lingkungan (Rusmilyansari 2012; Kartawijaya et al. 2011; Jamal 2015; Sutriyono et al. 2017). Oleh karena itu, diperlukan kebijakan pengelolaan trammel net berupa pengendalian jumlah alat tangkap (Rusmilyansari 2012).

Jenis multigear yang memiliki kinerja kurang layak dan tidak layak jumlahnya mencapai 9 jenis. Hal ini menunjukkan bahwa sebagian besar jenis multigear yang digunakan oleh nelayan Sungsang memiliki kinerja kurang layak. Jenis multigear tidak layak dan kurang sebaiknya diganti dengan jenis multigear yang layak. Upaya untuk merubah jenis multigear dapat dilakukan melalui kegiatan sosialisasi tentang kinerja setiap jenis multigear yang digunakan nelayan. Sosialisasi harus dilakukan secara terus menerus agar nelayan bersedia dan sukarela untuk memilih dari ke-2 jenis $m u$ Itigear unggulan. Selain itu, pengembangan jenis multigear unggulan harus dilakukan dengan mempertimbangkan prinsip kehatihatian. Hal ini mengingat bahwa penambahan jenis alat tangkap tersebut akan berdampak pada peningkatan tekanan terhadap keberlanjutan sumberdaya ikan itu sendiri. Dengan kata lain, pengembangan usaha perikanan tangkap harus memperhatikan status sumberdaya ikan yang menjadi target penangkapan, sehingga dalam jangka panjang tidak berdampak pada terjadinya overfishing. 


\section{KESIMPULAN}

Jenis multigear unggulan yang layak dikembangkan di Perairan Sungsang adalah: 1) kombinasi jaring udang dengan rawai hanyut; 2) kombinasi jaring insang hanyut (mesh, 3 inci) dengan rawai hanyut (umpan); dan 3) kombinasi jaring insang hanyut (mesh, 2 inci) dengan jaring udang.

\section{SARAN}

Saran yang dapat dirumuskan dari hasil penelitian ini adalah:

1. Diperlukan penelitian lanjutan untuk menentukan alokasi jumlah unit penangkapan multigear yang optimum.

2. Perlunya perumusan strategi pengembangan usaha perikanan tangkap multigear secara komprehensif.

\section{UCAPAN TERIMA KASIH}

Penelitian ini merupakan salah satu dari serangkaian riset yang didukung oleh dana Dipa Universitas Sriwijaya pada skema Unggulan Kompetitif bidang Pangan. Kami mengucapkan terima kasih kepada LP2M Unsri atas dukungannya sehingga rangkaian penelitian ini dapat terlaksana.

\section{DAFTAR PUSTAKA}

Béné C, Tewfik A. 2001. Fishing Effort Allocation and Fishermen's Decision Making Process in a Multi-Species Small-Scale Fishery: Analysis of the Conch and Lobster Fishery in Turks and Caicos Islands. Human Ecology. 29: 157-186.

BPS. 2015. Kabupaten dalam Angka 2015. Banyuasin: Badan Pusat Statistik Kabupaten Banyuasin. 284 hal.

Daw T. 2008. Spatial Distribution of Effort by Artisanal Fishers: Exploring Economic Factors Affecting The Lobster Fisheries of the Corn Islands, Nicaragua. Fisheries Research. 90: 17-25.

Dwirastina M, Abidin M. 2013. Konstruksi dan Hasil Tangkapan Jaring Trammel Net yang Beroperasi di Estuari Sungai Musi, Sumatera Selatan. BTL. 11(1): 19-22.
Fauziyah, Saleh K, Hadi, Supriyadi F. 2012. Respon Perbedaan Intensitas Cahaya Lampu Petromak terhadap Hasil Tangkapan Bagan Tancap di Perairan Sungsang Sumatera Selatan. Maspari Journal. 4(2): 215-224.

Fauziyah, Supriyadi F, Saleh K, Hadi. 2013. Perbedaan Waktu Hauling Bagan Tancap terhadap Hasil TangKapan di Perairan Sungsang, Sumatera Selatan. Jurnal Lahan Suboptimal. 2(1): 50-57.

Harahap N, Primiyastanto M, Purwanti P. 2000. Analisis Ekonomi Usaha Penangkapan Udang dengan Trammel net di Kabupaten Pasuruan. Jurnal Penelitian IImu-IImu Sosial. 12(1): 1-9.

Howara D, Laapo A. 2008. Analisis Determinasi Usaha Perikanan Tangkap Nelayan di Kabupaten Tojo UnaUna. J. Agroland. 15(4): 302-308.

Iskandar D, Guntur A. 2014. Efisiensi Teknis dan Ekonomi Alat Tangkap Garuk dan Peluang Pengembangannya di Desa Rawameneng, Kabupaten Subang. Maspari Journal. 6(2): 81-97.

Jamal M. 2015. Selektifitas Alat Tangkap Trammel Net terhadap Udang Penaeid di Kabupaten Takalar Propinsi Sulawesi Selatan. Torani (Jurnal IImu Kelautan dan Perikanan). 25(2): 96105.

Kartawijaya T, Ardani, Hamka E, Komarudin D, Jati AK, Thenu IM, Febri SP, Dirwana I, Gigentika S, Johannes S, Sholeh K. 2011. Analisis Tingkat Keramahan Lingkungan Alat Tangkap Trammel Net di Teluk Palabuhanratu. Buletin PSP. 19(2): 253-266.

Koeshendrajana S, Apriliani T, Firdaus M. 2012. Peningkatan Efektivitas dan Efisiensi Usaha Perikanan Tangkap Laut Skala Kecil Melalui Fasilitasi Peta Perkiraan Fishing Ground. J. Kebijakan Sosial Ekonomi Kelautan dan Perikan-an. 2(1): 77-88.

Maynou F, Recasens L, Lombarte A. 2011b. Fishing Tactics Dynamics of A Mediterranean Small-scale Coastal Fishery. Aquatic Living Resources. 24: 149159.

Moutopoulos DK, Ramfos A, Moukas C, Katselis D. 2014. Description of a Daily fishing Activity from a Small-Scale 
Fisherman in Central Greece (Korinthiakos Gulf). Int. Aquat Res. 6: 67-76.

Pet-Soede C, Van Densen WLT, Hiddink JG, Kuyl S. Macheils MAM. 2001. Can Fishermen Allocate Fishing Effort in Space and Time on the Basis of Their Catch Rates? An Example from Spermonde Archipelago, S. W. Sulawesi, Indonesia. Fisheries Management and Ecology. 8: 15-36.

Purbayanto A. 2005. Towards Sustainable Coastal Fisheries Development: A Case in Trammel Net Fishery in the Northern Coast of Java. Jurnal IImuilmu Perairan dan Perikanan Indonesia. 12(2): 87-95.

Rahmi TA, Nurani TW, Wahyuningrum PI. 2013. Usaha Perikanan Tangkap Skala Kecil di Sadeng, Provinsi Daerah Istimewa Yogyakarata. Jurnal "Amanisal" PSP FPIK Unpati-Ambon. 2(2): 40-45.

Rosalina D. 2011. Analisis Strategi Pengembangan Perikanan Pelagis di Kabupaten Banyuasin Provinsi Sumatera Selatan. J. Kebijakan Sosial Ekonomi Kelautan dan Perikanan. 1(1): 63-77.

Rusmilyansari. 2012. Inventarisasi Alat Tangkap Berdasarkan Kategori Status Penangkapan Ikan yang Bertanggung Jawab di Perairan Tanah Laut. Fish Scientiae. 2(4): 141-151.

Saldana A, Salas S, Arce-lbarra, TorresIrineo A. 2017. Fishing Operations and Adaptive Strategies of Small-Scale Fishers: Insights for Fisheries Management in Data-Poor Situations. Fisheries Management and Ecology. 24(1): 19-32.

Septifitri, Monintja DR, Wisudo SH, Martasuganda S. 2010. Analisis Kebutuhan
Sarana Perikanan dalam Rangka Pengembangan Perikanan Tangkap Berbasis Komoditas Unggulan di Propinsi Sumatera Selatan. Jurnal Saintek Perikanan. 5(2): 8-13.

Suharno, Susilowati I, Anggoro A, Yusuf EAG. 2016. Small-scale Fisheries Management for Traditional Shrimp Fishermen: A Bionomics Gamperts-fox Model. IJABER. 14(10): 6919-6924.

Sutriyono, Marsoedi, Afandhi A. 2017. Environmentally Friendly Analysis on Fishing Gear of Trammel Net in Cilacap, Central Java. J-PAL. 8(1): 19-24.

Torres-Guevara LE, Lopez MC, Schlüter A. 2016. Understanding Artisanal Fishers' Behaviors: The Case of Ciénaga Grande de Santa Marta, Colombia. Sustainability. 8: 549.

Wahyuningrum PI, Nurani TW, Rahmi RA. 2012. Usaha Perikanan Tangkap Multi Purpose di Sadeng, Kabupaten Gunungkidul, Daerah Istimewa Yogyakarta. Maspari Journal 4(1): 10-22.

Wismaningrum KEP, Ismail, Fitri ADP. 2013. Analisis Finansial Usaha Penangkapan One Day Fishing dengan Alat Tangkap Multigear di Pelabuhan Perikanan Pantai (PPP) Tawang Kabupaten Kendal. Journal of Fisheries Resources Utilization Management and Technology. 2(3): 263-272.

Wiyono ES. 2011. Alat Tangkap Unggulan di Kabupaten Bangka Selatan, Provinsi Bangka Belitung. Buletin PSP. 19(3): 229-238.

Yanuartono R, Ismail, Sardiyatmo. 2011. Analisis Kelayakan Finansial Usaha Perikanan Tangkap Multigear di Desa Margorejo Kecamatan Cepiring Kabupaten Kendal. Journal of Fisheries Resources Utilization Management and Technology. 2(3): 233-245. 